Solidaman Bertho Plaituka

Fakultas Hukum Univesitas Nusa Cendana

Jalan Adisucipto Penfui Kupang 85001 Nusa Tenggara Timur. Email: soliplaitukadgmail.com

\title{
Constitutional Complaint Dalam Rangka Penegakan Hak Asasi Manusia di Republik Indonesia
}

\begin{abstract}
The Constitutional Court exists to oversee the RI State Constitution contained therein and the protection of human rights enforcement. Protection of constitutional rights of citizens by the Court comes through constitutional review authority. But in the mechanism, the Court protect the constitutional rights of citizens to the extent of constitutional rights are violated by the provisions of the law, so the law will be declared contrary to the constitution. In fact, the possibility of violations of citizens' constitutional rights not only through the normative provisions of a law. There are many way and possible that violation of the constitutional rights of citizens, either by the authorities or by the actions of other parties. In this condition we know that constitutional complaint very urgent in Constitutional Court in Indonesia.

Keywords: Constitutional Complaint, Human Rights, Constitutional Court.
\end{abstract}

\section{ABSTRAK}

Mahkamah Konstitusi (MK) hadir untuk mengawal Konstitusi Negara RI yang didalamnya terkandung perlindungan dan penegakan HAM. Perlindungan hak-hak kontitusional warga negara melalui MK hadir melalui kewenangan constitutional review. Akan tetapi dalam mekanisme tersebut, MK melindungi hak-hak konstitusional warga negara sebatas terhadap hak konstitusional yang dilanggar oleh ketentuan-ketentuan dalam undang-undang, sehingga undang- undang tersebut nantinya dinyatakan bertentangan dengan konstitusi. Padahal, kemungkinan pelanggaran hak konstitusional warga negara tidak hanya melalui ketentuan normatif dalam suatu undang-undang. Banyak jalan dan kemungkinan terjadinya pelanggaran hak-hak konstitusional warga negara, baik oleh tindakan dari penguasa maupun oleh pihak-pihak lain. Disinilah kita mengetahui pentingnya mekanisme Constitutional Complaint di Mahkamah Konstitusi.

Kata Kunci: Constitutional Complaint, Hak Asasi Manusia, Mahkamah Konstitusi.

\section{PENDAHULUAN}

Gagasan konstitusi sebagai alat pembatas kekuasaan tidak dapat dipisahkan dengan gagasan perlindungan hak asasi manusia, negara demokratis dan negara hukum. Konstitusi merupakan kristalisasi normatif atas tugas negara dalam memberikan perlindungan hak asasi manusia dan melaksanakan pemerintahan berdasarkan kedaulatan rakyat disertai batasbatas kekuasaan secara hukum yang diarahkan 
bagi kepentingan dan kemaslahatan rakyat secara keseluruhan (Mahfud, 2003: 142). Pada kondisi inilah sistem kekuasaan negara akan disebut demokratis.

Perubahan konstitusi Indonesia yakni Undang-Undang Dasar Negara Republik Indonesia Tahun 1945 (UUD 1945) tahun 1999. 2002 telah membawa perubahan besar dalam sistem ketatanegaraan Indonesia, baik dalam pelembagaan kekuasaan legislatif, eksekutif, maupun yudikatif. Khusus dalam sistem kekuasaan kehakiman (yudikatif) di samping Mahkamah Agung (MA) dan badan-badan peradilan yang berada di bawahnya dalam lingkungan peradilan umum, lingkungan peradilan agama, peradilan milliliter, peradilan tatausaha Negara, telah muncul Mahkamah Konstitusi (MK).

Berdirinya Mahkamah Konstitusi dimulai dengan diadopsinya ide Constitusional Court dalam amandemen Konstitusi yang dilakukan oleh Majelis Permusyawaratan Rakyat (MPR) pada tahun 2001. Mahkamah Konstitusi dibentuk untuk menjamin agar konstitusi sebagai hukum tertinggi dalam Negara dapat ditegakkan sebagaimana mestinya. Berangkat dari pemikiran ini maka tidak heran Mahkamah Konstitusi disebut dengan Pengawal Konstitusi. Kehadiran Mahkamah Konstitusi cukup memberikan kontribusi yang signifikan dalam mengawal hak- hak konstitusional warga Negara yang selama rezim pemerintahan orde baru tidak pernah mendapat ruang yang cukup dalam penuntasannya.

Mahkamah Konstitusi merupakan Lembaga yudikatif yang sejak awal pembentukannya sampai dengan saat ini memiliki 4 wewenang yaitu: menguji undang-undang terhadap UUD 1945, memutus sengketa kewenangan lembaga negara yang kewenangannya diberikan oleh Undang-Undang Dasar 1945, memutus pembubaran partai politik, memutus perselisihan tentang hasil pemilihan umum, dan terdapat satu kewajiban nya yaitu memberikan putusan atas pendapat Dewan Perwakilan Rakyat mengenai dugaan pelanggaran oleh Presiden dan/atau Wakil Presiden menurut Undang-Undang Dasar (Pasal 24 UndangUndang Dasar 1945, Pasal 10 Undang- Undang Nomor 24 Tahun 2003 tentang Mahkamah Konstitusi).

Berdasarkan kewenangan Mahkamah Konstitusi tersebut, ketika terdapat pelanggaran terhadap hak asasi warga negara yang dijamin dalam konstitusi dan pelanggarannya terdapat dalam ketentuan aturan hukum atau regulasi dapat diluruskan melalui salah satu kewenangannya yaitu mekanisme constitutional review. Lantas, pertanyaannya adalah mekanisme apa yang dapat ditempuh untuk tindakan atau keputusan penyelenggara negara yang melanggar hak konstitusional warga negara?

Selain itu, bila kita membandingkan kewenangan Mahkamah Konstitusi di Indonesia dengan kewenangan Mahkamah Konstitusi pada umumnya yang berlaku pada negara lain, seperti telah disebutkan di atas, maka masih terdapat satu hal yang belum terakomodir dalam kewenangan MK yang diberikan oleh UUD 1945. Kewenangan tersebut adalah terkait penanganan terhadap pengaduan atau keluhan konstitusi oleh rakyat (constitutional complaint). Kenyataan tersebut bisa diartikan bahwa perlindungan hak asasi manusia setiap warga negara Indonesia yang diakui dan dilindungi oleh konstitusi, ternyata belum tersedia secara lengkap mekanisme dan prosedurnya di dalam konstitusi.

Demikian pula dalam mekanisme constitutional review yang kewenangannya diberikan kepada MK, memang telah terkandung semangat perlindungan hak-hak kontitusional warga negara. Akan tetapi, dalam mekanisme tersebut, MK melindungi hak-hak konstitusional warga negara sebatas terhadap hak konstitusional yang dilanggar oleh ketentuan- 


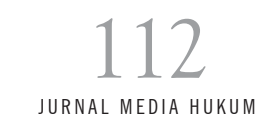

ketentuan dalam undang-undang, sehingga undang-undang tersebut nantinya dinyatakan bertentangan dengan konstitusi. Padahal, kemungkinan pelanggaran hak konstitusional warga negara tidak hanya melalui ketentuan normatif dalam suatu undang-undang. Banyak jalan dan kemungkinan terjadinya pelanggaran hak-hak konstitusional warga negara, baik oleh tindakan dari penguasa maupun oleh pihakpihak lain.

Berdasarkan hal-hal yang telah diuraikan tersebut, maka sudah seharusnya perlu adanya mekanisme perlindungan hak-hak konstitusional dengan proses dan prosedur yang dimuat dalam konstitusi. Perlindungan terhadap hak asasi manusia tidak hanya sebatas pengakuan terhadap hak asasi manusia dalam konstitusi, tetapi diperlukan mekanisme perlindungan yang jelas untuk menjamin terlaksananya perlindungan tersebut. Oleh karena itu, constitutional complaint merupakan sesuatu yang urgen untuk diadopsi sebagai kewenangan MK.

\section{PEMBAHASAN}

\section{A. URGENSI CONSTITUTIONAL COMPLAINT DI INDONESIA}

Di dalam negara hukum modern yang demokratis, constitutional complaint merupakan upaya hukum untuk menjaga secara hukum martabat yang dimiliki manusia yang tidak boleh diganggu gugat agar aman dari tindakan kekuasaan negara. Constitutional complaint merupakan mekanisme gugatan konstitusional sebagai salah satu alat bagi perlindungan hak asasi manusia. Constitutional complaint memberikan jaminan agar dalam proses-proses menentukan dalam penyelenggaraan negara, baik dalam pembuatan perundang-undangan, proses administrasi negara dan putusan peradilan tidak melanggar hak-hak konstitusional.

Constitutional complaint menjadi upaya hukum yang luar biasa dalam mempertahankan hak-hak konstitusional bagi setiap individu warga negara. Proses gugatan konstitusional ini merupakan wujud pengaduan masyarakat atas keberatan terhadap perilaku kinerja pemerintah terhadap rakyat, peraturan perundang-undangan dan putusan pengadilan yang dianggap bertentangan dengan hak asasi manusia yang diatur dalam konstitusi.

Sehubungan dengan itu pada prinsipnya, constitutional complaint merupakan metode untuk memperjuangkan agar hak-hak dasar seseorang tidak terciderai oleh tindakan negara. Dalam hal ini, constitutional complaint memiliki makna istimewa yaitu terkait dengan kedudukan manusia dalam sebuah negara. Setiap warga negara dalam negara hukum modern yang demokratis merupakan bagian dari pemilik kedaulatan dimana semua kekuasaan negara sesungguhnya berasal dari rakyat. Di dalam negara yang berkedaulatan rakyat, constitutional complaint menjadi semacam pengakuan bahwa rakyat adalah pemegang kedaulatan. Melalui constitutional complaint inilah kemudian warga negara sebagai bagian rakyat yang berdaulat diikutsertakan secara efektif dalam mekanisme kelembagaan negara terutama pada proses pengawasan terhadap lembaga-lembaga konstitusional melalui peradilan konstitusional. Dengan demikian hak dan martabat manusia diakui dan dilindungi secara efektif melalui sebuah kekuasaan peradilan konstitusional.

Indonesia merupakan negara hukum yang berkedaulatan rakyat atau demokratis, sekaligus negara demokratis yang berdasar hukum. UUD 1945 telah mengatur dan menjamin hak konstitusional warga negara. Pengaturan dan jaminan pengakuan hak asasi manusia antara lain dinyatakan dalam Pasal 27, 28 dan 29 UUD 1945. Secara kuantitas Pasal 28 UUD 1945 telah sangat akomodatif untuk mengakui dan menjamin hak-hak konstitusional warga negara.Tentu saja jaminan hak asasi manusia 
tersebut berlaku untuk semua warga negara tanpa kecuali dan tanpa membedakan warga negara dengan unsur-unsur pembeda seperti suku, ras dan agama.

Selain dalam Bab Hak Asasi Manusia maupun ketentuan konstitusi yang dirumuskan dengan kata "hak", kewajiban negara untuk menyediakan pendidikan dasar, prioritas anggaran pendidikan sebesar 20 persen dari APBN dan APBD (Pasal 34), atau kewajiban negara untuk menyediakan jaminan sosial, juga menimbulkan hak konstitusional bagi warga negara.

Pertanyaannya kini adalah, apakah hak-hak konstitusional yang sudah diakui dan dijamin oleh konstitusi tersebut telah benar-benar mendapat perlindungan dan telah disediakan upaya hukum yang cukup ketika hak itu dilanggar. Kasus Ahmadiyah yang terjadi di desa Cikeusik Padeglang Banten merupakan contoh kasus yang terkait dengan pelanggaran hak konstitusional yang berujung pada pembunuhan beberapa orang di hari minggu 6 Februari 2011 (http://m.tempo.co/read/news/2011/02/06/ 179311441/Kronologi-Penyerangan-JamaahAhmadiyah-di-Cikeusik, akses 11 November 2013).

Kemudian terbitlah SKB 3 Menteri tentang Peringatan dan Pelarangan Aktivitas Jamaah Ahmadiyah Islam (JAI) tanggal 9 Juni 2008 yang ditandatangani oleh Menteri Agama, Jaksa Agung dan Menteri Dalam negeri (http:// sumut.kemenag.go.id/file/file/SKB/ qecr1362680584.pdf, akses 11 November 2013), hal tentunya bertentangan dengan hak konstitusional seperti yang diatur dalam Pasal 29 Ayat (2) UUD 1945 tentang kebebasan beragama. SKB ini kemudian di ujikan ke MK namun ditolak dengan pendapat bahwa dalil pemohon tidak tepat karena untuk menguji SKB bukan kewenangan MK (https:// sahanamyna.wordpress.com/2010/04/20/ alasan-mk-menolak-uji-uu-penodaan-agama-2/ diakses 11 November 2013). Terhadap SKB tersebut Mahfud MD berpendapat bahwa SKB tiga Menteri tentang pelarangan Jemaah Ahamdiyah itu tidak dapat digugat ke Mahkamah Konstitusi, Mahkamah Agung maupun PTUN. Berikut pernyataan Mahfud MD tentang SKB tersebut: (https:// sahanamyna.wordpress.com/2010/04/20/ alasan-mk-menolak-uji-uu-penodaan-agama-2/, akses 11 November 2013)

"Mahkamah Konstitusi tidak berwenang menilai SKB Ahmadiyah.Berdasarkan ketentuan Pasal 24 C UUD 1945, Mahkamah Konstitusi hanya berwenang melakukan pengujian undang-undang terhadap Undang-Undang Dasar. Dibawa ke MA juga tidak tepat, karena SKB bukan peraturan perundang-undangan, sebagaimana diatur dalam Undang- Undang Nomor 12 Tahun 2011 dan Jika diperkarakan ke PTUN juga kurang tepat karena SKB tersebut dapat dinilai sebagai peraturan bukan penetapan karena ada muatannya yang bersifat umum dan benar terjadi ketika ahmadiyah menggugat ke PTUN ditolak karena PTUN mengadili kasus yang bersifat individual konkrit."

Kasus berikutnya yaitu kasus Majalah Playboy Indonesia, dimana setelah melakukan penerbitan majalah ini pada tanggal 7 April 2006 di Indonesia pimpinan nya ditangkap dan terjadi pengrusakan bahkan pembakaran kantor Majalah Playboy di Jalan TB Simatupang Jakarta Selatan oleh Front Pembela Islam (FPI) (https:// m.tempo.co/read/news/2010/08/27/

063274387/kasus-playboy-indonesia-dari-terbithingga-tutup-kontroversial, akses 11 November 2013). Terkait kasus Majalah Playboy berkaitan dengan hak konstitusional yang diatur dalam Pasal 28E Ayat (3) UUD 1945 yang menegaskan bahwa setiap orang berhak atas kebebasan berserikat, berkumpul, dan mengeluarkan pendapat.

Kasus tersebut merupakan contoh yang menunjukkan bahwa warga negara tidak 
berpeluang mempertahankan dan memperjuangkan hak konstitusionalnya ketika dilanggar. Padahal dalam negara hukum yang demokratis, seperti yang diinginkan Indonesia dalam UUD 1945, harapan terselenggaranya kehidupan demokratis yang berdasar hukum (rule of law) dengan adanya jaminan perlindungan konstitusional. Perlindungan tersebut, bukan hanya sebatas jaminan dan pengakuan hak-hak konstitusional warga negara, tetapi juga diharapkan untuk menentukan pula cara prosedur untuk memperoleh perlindungan atas hak-hak dasar tersebut.

Sehubungan dengan upaya perlindungan hak-hak konstitusional inilah constitutional complaint dapat dijadikan solusi dan mendapatkan tempat dalam upaya perwujudan negara demokratis yang berdasar hukum, sekaligus negara hukum yang demokratis. Dengan mengakomodir constitutional complaint ke dalam konstitusi, maka perlindungan hak-hak konstitusional akan memperoleh jaminan dan kepastian dalam pelaksanaannya, bukan sekedar normatif saja.

Perlindungan terhadap hak konstitusional adalah salah satu isu mendasar dalam konstitusi. Maka dari itu penulis mencoba mengungkapkan beberapa alasan mengapa constitutional complaint menjadi sesuatu yang sangat urgen dan perlu diadopsi dalam sistem ketatanegaraan Indonesia dan menjadi kewenangan dari MK.

Pertama, dilihat dari sisi sejarah, hak konstitusional merupakan hak dasar yang tidak hanya berhubungan dengan konstitusi melainkan merupakan bagian dari konstitusi. Hak konstitusional yang bermula dari konsep individual rights atau hak- hak individu yang diturunkan dari pemikiran hak-hak alamiah atau nature rights (Basu, 2003: 48-78). Ketika dituangkan dalam dan menjadi bagian dari konstitusi maka itu akan mengikat seluruh cabang kekuasaan negara. Taat dan patuh terhadap hak- hak -hak tadi merupakan sesuatu yang harus dipaksakan. Salah satu bentuk pemaksaan itu adalah putusan pengadilan. Constitutional Complaint hadir di sini untuk mempertahankan hak- hak konstitusional yang dimiliki oleh warga negara. Di sisi lain fungsi MK sebagai pengawal konstitusi maka kewenangan untuk mengadili Constitutional Complaint seharusnya diberikan kepada MK.

Kedua, tidak adanya kewenangan MK untuk mengadili Constitutional Complaint menyebabkan tidak tersedianya upaya hukum melalui peradilan konstitusional untuk pelanggaran terhadap hak- hak konstitusional warga negara yang terjadi bukan karena inkonstitusionalitas norma Undang-Undang melainkan karena adanya perbuatan maupun kelalaian lembaga negara atau pejabat publik. Sementara semua upaya hukum yang tersedia berdasarkan sistem yang berlaku saat ini telah ditempuh oleh pihak pengadu atau pelapor. Salah satu akibatnya yang dapat kita lihat saat ini dimana banyak permohonan yang diajukan ke MK, yang secara substansial merupakan Constitutional Complaint dinyatakan tidak dapat diterima (niet ontvankelijk verklaard) dengan alasan MK tidak berwenang untuk mengadilinya (Faiz, http:// jurnalhukum.blogspot.com/2006/09/constitutionalcomplaint-dan-hak-asasi, akses 23 Januari 2013: 2), menyatakan bahwa surat-surat maupun permohonan yang diterima oleh Kepaniteraan Mahkamah Konstitusi selama tahun 2005, sedikitnya terdapat 48 surat ataupun permohonan yang dapat dikategorikan sebagai bentuk constitutional complaint atau sejumlah 3 (tiga) kali lipat permohonan judicial review pada tahun yang sama). Jika hal ini dibiarkan terus-menerus, maka jelas kontradiktif dengan gagasan negara hukum sebagai salah satu gagasan pokok yang mendasari dilakukannya perubahan terhadap UUD 1945.

Ketiga, dalam sistem yang berlaku saat ini, upaya hukum yang tersedia bagi warga negara untuk mempertahankan hak- hak 
konstitusionalnya melalui proses peradilan konstitusional di MK hanyalah melalui mekanisme pengujian Undang- Undang terhadap Undang- Undang Dasar. Dengan kata lain, sistem yang berlaku saat ini mengasumsikan seolah- olah pelanggaran terhadap hak- hak konstitusional warga negara itu hanya terjadi jika pembentuk undangundang yakni DPR bersama Presiden membuat undang- undang yang ternyata melanggar hak konstitusional warga negara. Padahal, sebagaimana telah diuraikan sebelumnya pelanggaran terhadap hak konstitusional warga negara tersebut tidak hanya terjadi karena kesalahan undang- undang tetapi juga karena perbuatan atau kelalaian pejabat publik. Keadaan demikian menjadi gejala akhir-akhir ini dimana mereka yang menganggap hak konstitusional mereka dilanggar mengajukan permohonan pengujian undang- undang padahal norma yang diuji padahal norma yang diuji sama sekali tidak mengandung materi muatan yang bersifat inkonstitusional atau mereka mencoba cara lain, yakni dengan membuat konstruksi hukum seolah-olah terjadi sengketa kewenangan antar lembaga dengan harapan hal itu dapat memulihkan kerugian dan atau kewenangan konstitusional yang mereka alami.

Keempat, tidak dimilikinya kewenangan mengadili Constitutional Complaint oleh MK juga kontradiktif dengan sejarah kelahiran gagasan MK. Lahirnya MK di samping untuk menegakkan prinsip negara hukum juga dilandasi keinginan yang kuat untuk memberikan perlindungan maksimum terhadap demokrasi dan hak- hak dasar warga negara. Pemberian kewenangan untuk mengadiili perkara Constitutional Complaint kepada MK akan memberikan kontribusi pada upaya memperkuat penghormatan terhadap hak- hak dan kebebasan - kebebasan mendasar manusia mengintensifkan perlindungan terhadap hak- hak tersebut dan mempetegas derajat konstitusionalnya.

\section{B. PERKEMBANGAN CONSTITUTIONAL COMPLAINT DI INDONESIA}

Ditinjau dari sejarah pembentukan MK yang dituangkan dalam UUD ada satu perdebatan menarik yang menjadi topik bahasan dalam pembicaraan tentang kewenangan MK. Namun salah satu hal yang pasti adalah keinginan untuk membentuk MK didorong oleh gagasan mengejawantahkan fungsi pengujian konstitusional, khususnya pengujian konstitusionalitas Undang-Undang. Hal ini sudah mengemuka dalm sidang- sidang Panitia Ad hoc III (selanjutnya disingkat PAH) BP MPR tahun 1999. Fraksi- fraksi di MPR saat itu berpendapat banyak terdapat undang- undang yang bertentangan dengan UUD sementara mekanisme untuk melakukan koreksi terhadap Undang- Undang tersebut melalui pengujian di Peradilan akan kesesuaiannya dengan UUD tidak ada. Oleh karena itu ada lembaga yang memiliki kewenangan untuk melakukan fungsi itu sudah dirasakan sebagai kebutuhan (Palguna, 2013: 561).

Dorongan kearah pembentukan lembaga demikian makin menguat dengan telah melembaganya kesadaran akan pentingnya perlindungan yang nyata terhadap HAM yang dikonsepsikan sebagai hak konstitusional. Suarasuara tentang perlunya perlindungan yang nyata terhadap HAM dengan membentuk MK yang tadinya lebih banyak hidup dalam kesadaran kelompok organisasi non pemerintahan saat ini telah pula menjadi bagian dari mereka yang duduk di Lembaga Negara khususnya DPR dan MPR

Selanjutnya dalam perkembangan perdebatan mengenai kewenangan MK salah satu yang secara eksplisit mengusulkan agar MK yang akan dibentuk itu diberi wewenang Constitutional Complaint adalah Fraksi PDIP namun istilah 


\section{6 \\ JURNAL MEDIA HUKUM}

yang digunakan adalah "gugatan yang

berdasarkan Undang- Undang Dasar”. Usulan tersebut dikemukakan sebagai pendapat akhir Fraksi pada Rapat pleno ke 41 PAH I BP MPR. Dalam usulan tersebut dikatakan antara lain:

Pasal berikutnya atau pasal 29 dalam usulan kami:

Ayat (1) Di dalam lingkungan Mahkamah Agung dibentuk Mahkamah Konstitusi;

Ayat (2) MK memiliki kewenangan untuk menguji Undang- Undang dan peraturan perundangan di bawah Undang- Undang; memberi pertimbangan kepada DPR dalam hal DPR hendak meminta persidangan MPR mengenai laporan perilaku presiden yang mengkhianati negara dan / atau merendahkan maratabat lembaga kepresidenan; memberi keputusan akhir mengenai putusan pembubaran suatu partai politik; memberi putusan apabila terdapat perselisihan antara pemerintah pusat dengan pemerintah daerah otonom: memberikan putusan atau gugatan yang berdasarkan UUD.... (Risalah Rapat Pleno ke 41 Panitia Ad Hoc I Badan Pekerja MPR 2000, 8 Juni 2000: 24-25). Yang dimaksudkan dengan gugatan berdasarkan UUD substansinya tidak lain adalah Constitutional Complaint.

Namun usulan ini kemudian tidak diteruskan karena dua alasan: Pertama, ada kekhawatiran apabila kewenangan memutus Constitutional Complaint itu diberikan kepada MK akan segera terjadi penumpukan perkara. Kedua karena masih merupakan hal baru, dikhawatirkan akan ada tumpah tindih dengan kewenangan pengadilan dalam lingkungan perdilan umum (misalnya apakah MK juga memutus persoalan penentuan ganti kerugiannya dalam perkara Constitutional Complaint itu.

Sementara dalam diskusi dalam tim internal PDIP, selaku fraksi yang mengusulkan agar kewenangan itu diberikan kepada $\mathrm{MK}$, pembahasan mengenai kewenangan untuk memutus "gugatan berdasarkan UUD atau Constitutional Complaint itu disepakati untuk tidak diteruskan setelah ketua tim Jacob Tobing memaparkan pengalaman MK afrika Selatan dan MK Jerman.

Di Afrika Selatan di mana terdapat kemungkinan bahwa putusan MA Afrika Selatan dapat dibatalkan oleh MK melalui mekanisme gugatan atas dasar konstitusi (istilah yang digunakan pada saat itu) sehingga timbul semacam ketidak pastian hukum juga. Sedangkan pengalaman jerman yang menurut informasi saat itu, menerima perkara Constitutional Complaint rata- rata 6 ribu perkara pertahun ikut memberikan andil bagi diambilnya keputusan internal untuk tidak meneruskan usulan itu dengan alasan bahwa kita belum siap ((Risalah Rapat Pleno ke 41 Panitia Ad Hoc I Badan Pekerja MPR 2000, 8 Juni 2000: 563).

Sebagaimana telah diketahui, dalam UUD 1945 telah dinyatakan secara tegas bahwa Indonesia adalah negara hukum yang kemudian diikuti dengan pembentukan MK, maka secara teoritik pada saat itu sesungguhynya adanya mekanisme Constitutional Complaint telah menajdi kebutuhan teoritik. Sebab satu hal yang pasti adalah bahwa setiap negara hukum senantiasa menempatkan konstitusi sebagai bagian dari hukum tertinggi dan didalam konstitusi terdapat salah satu bagain yang sangat fundamental yakni HAM.

Terkait dengan mekanisme constitutional complaint setiap tahunnya terhadap surat-surat maupun permohonan yang diterima oleh Kepaniteraan Mahkamah Konstitusi sejak tahun 2005, sedikitnya terdapat 48 surat ataupun permohonan yang dapat dikategorikan sebagai bentuk constitutional complaint atau sejumlah 3 (tiga) kali lipat permohonan judicial review pada tahun yang sama (Faiz, http:// jurnalhukum.blogspot.com/2006/09/constitutional-complaint-dan-hak-asasi, akses 23 Januari 
2013: 2).

Melihat dari kenyatan di Indonesia kita dapat melihat bahwa Constitutional Complaint merupakan suatu yang urgen karena masalah dan pelanggaran terhadap hak konstitusional warga negara tengah marak terjadi dan tidak ada lembaga peradilan manapun yang dapat memutus sengketa ataupun masalah ini. Sehingga wacana yang pernah dilemparkan oleh fraksi PDIP dalam pembahasan kewenangan MK oleh MPR perlu dihidupkan kembali dan dimaknai sebagai suatu yang harus ada di negara Indonesia.

Di samping itu perlu juga dicermati mengenai pembentukan kewenangan Mahkamah Konstitusi, bahwa ide untuk memasukkan mekanisme constitutional complaint ini juga dilontarkan oleh Komisi Konstitusi setelah proses perubahan keempat UUD 1945 disahkan. Mengenai draft tandingan oleh Komisi Konstitusi, diusulkan bahwa dalam pasal 24 ayat (1) hasil perubahan ketiga UUD 1945 ditambah dengan kewenangan constitutional complaint. Adapun draf tandingan tersebut dapat dilihat sebagai berikut (Laksono, Jurnal Konstitusi, vol. 4 nomor 4, Desember 2007: 138):

a. Kewenangan Mahkamah Konstitusi hasil amandemen yaitu: MahkamahKonstitusi berwenang mengadili pada tingkat pertama dan terakhir yang putusannya bersifat final untuk menguji undang-undang terhadap Undang- Undang Dasar, memutus sengketa kewenangan lembaga Negara yang kewenangannya diberikan oleh UndangUndang Dasar, memutus pembubaran partai politik, dan memutus perselisihan tentang hasil pemilihan umum.

b. Kewenangan Mahkamah Konstitusi hasil draft Komisi Konstitusi yaitu: Mahkamah Konstitusi berwenang mengadili pada tingkat pertama dan terakhir yang putusannya bersifat final untuk menguji undang-undang terhadap Undang-Undang Dasar, memutus sengeta kewenangan lembaga Negara yang kewenangannya diberikan oleh UndangUndang Dasar, memutus pembubaran partai politik, dan memutus perselisihan tentang hasil pemilihan umum dan memutus pengaduan pelanggaran hak konstitusionalwarga negara.

\section{Impikasi Hukum diadopsinya Constitu- tional Complaint di Indonesia}

Implikasi hukum yang paling akan sangat memberikan dampak yakni berkaitan dengan tugas dan wewenang MK. MK sepatutnya memiliki kewenangan constitutional complaint, sebab kedudukan MK akan menjadi keluar dari tujuan didirikannya apabila tetap berpegang teguh pada constitutional review.

Karena setiap produk dari lembaga negara diluar legislatif, tindakan pejabat publik dan putusan final pengadilan umum yang melanggar hak-hak konstitusional warga negara tidak akan dapat ditindak oleh MK. Bukankah tujuan didirikannya MK tidak semata-mata untuk melindungi warga negara dari tindakan sewenang- wenang negara yang selalu dijelmakan dalam produk hukum (legislasi), tapi pada dasarnya sebagai penjaga dan pelindung konstitusi. Sehingga seharusnya setiap pelanggaran konstitusi, baik dalam bentuk peraturan perundang-undangan maupun dalam bentuk tindakan dan kebijakan pejabat publik, dapat dimohonkan penyelesaiannya kepada MK.

Di lain sisi, upaya hukum pengaduan konstitusional melalui judicial review terlalu prosedural dan tidak secara langsung mengena pada pelanggaran konstitusional. Seseorang yang merasa haknya terlanggar oleh perbuatan pejabat publik harus terlebih dahulu mengajukan pembatalan peraturan perundangundangan terkait sebelum memperoleh justifikasi bahwa haknya memang telah dilanggar oleh perbuatan pejabat publik dan 




putusan final pengadilan umum.

Padahal hemat penulis, suatu pelanggaran hak-hak konstitusional seharusnya dapat langsung dituntut tanpa membatalkan peraturan perundang-undangan bersangkutan terlebih dahulu. Tentu saja dengan menggunakan konstitusi sebagai batu ujinya. Lagi pula tidak semua pelanggaran konstitusi bersumber dari terlanggarnya hak-hak konstitusional dari diberlakukannya suatu undang-undang.

Hal tersebut karena, bisa jadi suatu undangundang telah sesuai dengan konstitusi, akan tetapi tindakan pejabat publik dalam menjalankan maksud dari undang-undang tersebut melanggar hak-hak konstitusi masyarakat.

Dengan demikian, kebutuhan akan instrumen perlindungan hak-hak konstitusi berupa constitutional complaint seharusnya berangkat dari empat kesadaran. Pertama, kesadaran akan adanya suatu tindak pelanggaran hak-hak konstitusional yang dilakukan oleh state apparatus.

Kedua, kesadaran akan adanya suatu pelanggaran hak-hak konstitusional yang merupakan akibat dari dikeluarkannya suatu putusan pengadilan umum. Ketiga, kesadaran bahwa dengan tidak diaturnya atau dikeluarkannya suatu peraturan perundangundangan akan melanggar hak-hak konstitusional. Keempat, pengakuan terhadap MK sebagai pelindung konstitusi. Dengan kesadaran tersebut, mekanisme constitutional complaint niscaya dan mutlak diperlukan.

Kewenangan MK untuk memutus constitutional complaint saat ini masih terkendala karena kewenangan tersebut masih belum termuat secara ekplisit di dalam UUD 1945. Tetapi dengan mengingat pentingnya perlindungan terhadap hak konstitusional warga negara, maka fungsi MK sebagai lembaga pengawal konstitusi dipandang perlu memiliki kewenangan constitu- tional complaint. Selama ini salah satu kewenangan MK adalah menguji UndangUndang terhadap UUD 1945 (Judicial review), yang berarti hanya sebatas pelanggaran hak konstitusional warga negara dalam bentuk undang-undang.

Ketentuan yang mengatur mekanisme constitutional complaint di Indonesia belum termuat secara eksplisit di konstitusi, artinya tidak tertulis dalam UUD 1945. Namun secara tersirat terkandung adanya hak-hak konstitusional warga yang dilindungi oleh negara. Sehingga bagi setiap warga negara yang merasa hak-hak konstitusionalnya dilanggar oleh tindakan penguasa dapat mengajukan perkara kepada lembaga peradilan yang berwenang, dalam hal ini adalah MK (sesuai fungsinya sebagai pengawal konstitusi). Hal tersebut terkait erat dengan teori pembangunan hukum responsif, yakni teori yang menyatakan bahwa bingkai hukum pada prinsipnya harus partisipatif, serta berisi nilai-nilai yang tepat berdasarkan asas-asas hukum yang berkembang dalam masyarakat.

\section{SIMPULAN}

Berdasarkan uraian dan pembahasan diatas maka kesimpulan yang dapat ditarik yaitu keberadaaan constitutional complaint sebagai kewenangan Mahkamah Konstitusi sudah merupakan sebuah kebutuhan yang mendesak dan sangat urgen untuk diberlakukan dalam Negara Kesatuan Republik Indonesia. Constitutional complaint bukan merupakan hal baru di Indonesia karena constitutional complaint sudah pernah diwacanakan sebagai salah satu kewenangan MK pada saat Rapat pleno Pembentukan MK dan juga oleh Komisi Konstitusi melalui draft tandingan terkait kewenangan MK. Sehingga dengan demikian jika kewenangan constitutional complaint bagi MK diadopsi maka implikasi hukumnya adalah terciptanya perlindungan Hak Asasi warga 
negara Indonesia dari tindakan aparat

Pemerintah ataupun oknum yang mencederai

Hak Asasi warga Negara dan pengakuan

terhadap MK sebagai pengawal Konstitusi.

\section{DAFTAR PUSTAKA}

Assidique, Jimly. 2005. Konstitusi dan Konstitusionalisme. Jakarta: Konpress

Durga Das Basu,2003. Human Rights In Constitutional Law. Wadhawa and Company, New Delhi

Laksono Fadjar, Meretas Constitutional Complaint ke dalam UUD 1945: Menuju Konstitusi yang Lebih Demokratis, Jurnal Konstitusi, vol. 4 nomor 4, Desember 2007

Mahfud MD, Mohammad. 2003. Demokrasi dan Konstitusi di Indonesia. Jakarta: Rineka Cipta

Mohamad Faiz, Pan, http: //jurnalhukum.blogspot.com/2006/09/ constitutional-complaint-dan-hak-asasi. Menabur Benih Constitutional Complaint

Palguna, ID Gede.2013. Pengaduan Konstitusional upaya hukum terhadap pelanggaran hak- hak konstitusional warga negara, Jakarta: Sinar Grafika

Risalah Rapat Pleno ke 41 Panitia Ad Hoc I Badan Pekerja MPR 2000

Thaib,Dahlan dkk.2011:Teori dan Hukum Konstitusi, Jakarta:Raja Grafindo Perkasa

Surat Keputusan Bersama Tiga Menteri tentang Pelarangan Jamaah Isalam Ahmadiyah http://sumut.kemenag.go.id/file/file/SKB/ qecr1362680584.pdf

http://m.tempo.co/read/news/2011/02/06/179311441/KronologiPenyerangan-Jamaah-Ahmadiyah-di-Cikeusik

https://m.tempo.co/read/news/2010/08/27/063274387/kasusplayboy-indonesia-dari-terbit-hingga-tutup-kontroversial

http// www. hukumpedia. com// SKB 3 Menteri tentang ahmadiyah bukan kewenangan MK diakses tanggal 23 Januari 2013

Peraturan Perundang-undangan dan Putusan Pengadilan Undang- Undang Dasar Negara Republik Indonesia Tahun 1945

Undang- Undang Nomor 24 Tahun 2003 tentang Mahkamah Konstitusi

Putusan Mahkamah Konstitusi RI Nomor 002/SKLN-IV/2006

Putusan Mahkamah Konstitusi RI Nomor 004/SKLN-IV/2006 